Int. J. Electrochem. Sci., 12 (2017) 1389 - 1400

\title{
Highly Effective PdCu Electrocatalysts Supported on Polyelectrolyte Functionalized Titanium Dioxide for Direct Formic Acid Fuel Cells
}

\author{
Qizhi Dong*, Wenxia Zeng,Hansheng Wan, Shumin Yu, Cancheng Guo*, Meiling Huang
}

State Key Laboratory of Chemo/Biosensing and Chemometrics, College of Chemistry and Chemical Engineering, Hunan University, Changsha 410082, PR China

*E-mail: qzhdong67@163.com

doi: $10.20964 / 2017.02 .02$

Received: 25 October 2016 / Accepted: 12 December 2016 / Published: 30 December 2016

\begin{abstract}
A highly efficient and $\mathrm{CO}$ tolerant $\mathrm{PdCu}$ electrocatalysts supported on amino-rich, cationic poly(diallyl dimethyl ammonium chloride)(PDDA) functionalized $\mathrm{TiO}_{2}\left(\mathrm{PdCu} / \mathrm{TiO}_{2}(\mathrm{P})-\mathrm{C}\right)$ has been developed. The catalysts were characterized by transmission electron microscopy (TEM),X-ray diffraction (XRD), cyclic voltammograms and chronoamperometry. The $\mathrm{PtCu}$ particles with average size $\sim 3.5 \mathrm{~nm}$ are well dispersed on $\mathrm{TiO}_{2}(\mathrm{P}) . \quad \mathrm{PdCu} / \mathrm{TiO}_{2}(\mathrm{P})-\mathrm{C}$ catalysts exhibit a superior electrocatalytic activity and stability for the formic acid oxidation reaction compared with the $\mathrm{Pd} / \mathrm{TiO}_{2}(\mathrm{P})-\mathrm{C}$. Electrochemical measurements indicate that $\mathrm{PdCu} / \mathrm{TiO}_{2}(\mathrm{P})-\mathrm{C}(1: 2)$ catalyst has the best performance for formic acid electro-catalytic oxidation in terms of durability and Pd-mass activity among three catalysts $\left(\mathrm{Pd}_{1} \mathrm{Cu}_{1}, \mathrm{Pd}_{1} \mathrm{Cu}_{2}, \mathrm{Pd}_{1} \mathrm{Cu}_{3}\right)$. The possible reason is that the addition of $\mathrm{Cu}$ is beneficial to lower appropriately the d-band center of $\mathrm{Pd}$ and increase the electrochemical active surface area of the $\mathrm{PdCu} / \mathrm{TiO}_{2}(\mathrm{P})-\mathrm{C}$ nanocatalysts, but when the content of $\mathrm{Cu}$ rises to a certain extent, the morphology of the catalyst nanoparticles will transform into linear structure leading to increased particle size.
\end{abstract}

Keywords: Formic acid fuel cells; $\mathrm{PdCu}$; electrocatalysts; titanium dioxide

\section{FULL TEXT}

(C) 2017 The Authors. Published by ESG (www.electrochemsci.org). This article is an open access article distributed under the terms and conditions of the Creative Commons Attribution license (http://creativecommons.org/licenses/by/4.0/). 